\title{
Structural chromosome polymorphism in a Pimelodus maculatus La Cepède, 1803 population (Siluriformes, Pimelodidae) from the Paranapanema River Basin, PR, Brazil
}

\author{
Mazzuchelli, J. ${ }^{\text {a }}$ Swarça, AC. ${ }^{\text {b }}$ and Dias, AL. ${ }^{\text {a* }}$ \\ aDepartamento de Biologia Geral, Centro de Ciências Biológicas - CCB, Universidade Estadual de Londrina, \\ Rodovia Celso Garcia Cid, PR 445, CP 6001, CEP 86051-970, Londrina, PR, Brazil \\ bepartamento de Histologia, Universidade Estadual de Londrina, Londrina, PR, Brazil \\ *e-mail: anadias@uel.br
}

Received May 8, 2005 - Accepted August 30, 2007 - Distributed December 1, 2007

(With 2 figures)

\begin{abstract}
In the present cytogenetic study of Pimelodus maculatus, 13 specimens ( 8 males and 5 females) from the Congonhas Stream in Paraná State, Brazil, were examined using conventional staining. All of them showed a karyotype of $2 \mathrm{n}=56$, with a chromosome distribution of $20 m+20 s m+10 s t+6 a$. However, four individuals ( 2 males and 2 females) were found to have a variant karyotype (cytotype) with two heteromorphic chromosomes in the group of submetacentric chromosomes - one of them corresponds to the second largest chromosome of this group and the other is a chromosome of small size. This variation suggests the existence of a structural polymorphism in the studied population.
\end{abstract}

Keywords: Pimelodus, Pimelodidae, polymorphism, cytotype.

\section{Polimorfismo cromossômico estrutural em uma população de Pimelodus maculatus La Cèpede, 1803 (Siluriformes, Pimelodidae) da bacia do Rio Paranapanema, PR, Brasil}

\begin{abstract}
Resumo
No presente estudo citogenético, foram analisados, mediante coloração convencional, 13 exemplares de Pimelodus maculatus, (8 machos e 5 fêmeas), do ribeirão Congonhas, PR, Brasil. Todos apresentaram um cariótipo com 2n $=56$, distribuídos em 20 cromossomos metacêntricos (m), 20 submetacêntricos (sm), 10 subtelocêntricos (st) e 6 acrocêntricos (a). Entretanto, 4 indivíduos (2 machos e 2 fêmeas) apresentaram um cariótipo variante (citótipo) com dois cromossomos heteromórficos no grupo dos submetacêntricos, sendo um deles o segundo maior deste grupo e o outro de tamanho pequeno. Esta variação sugere a ocorrência de um polimorfismo estrutural na população estudada.
\end{abstract}

Palavras-chave: Pimelodus, Pimelodidae, polimorfismo, citótipo.

\section{Introduction}

Neotropical fish show a high chromosomal diversity with variations in diploid number, ploidy level, sex chromosomes, and supernumerary chromosomes, and many cases of structural variations called polymorphisms (Galetti, 1998). Chromosomal variations can be advantageous, disadvantageous, or neutral. Disadvantageous variations are rapidly eliminated from populations, while advantageous and neutral ones can be transmitted to descendents and can contribute to karyotypic variations in the species.

Based on cytogenetic data for the family Pimelodidae, Garcia and Moreira-Filho (2005) considered pericentric inversions to be an important, if not the most common, rearrangement in the karyotypic differentiation of the family, maintaining the diploid number of $2 n=56$ but diversifying chromosomal morphology.
The genus Pimelodus includes the most cytogenetically studied pimelodids, and a diploid number of $2 n=56$ was found in the majority of its species, with some variations in the karyotype formula (Souza et al., 2003, 2004; Borin and Martins-Santos, 2004). In this fish group, Dias and Foresti (1993) found a structural chromosome polymorphism in Pimelodus maculatus and Pimelodus sp. from the São Francisco River, probably related to chromosomal rearrangements such as pericentric inversions and deletions.

The aim of this work was to describe the chromosomal constitution of a population of Pimelodus maculatus La Cepède, 1803 from the Congonhas Stream, a tributary of the Paranapanema River, where divergent karyotypes were found among specimens of this population. 


\section{Material and Methods}

Chromosomes of thirteen specimens of Pimelodus maculatus ( 8 males and 5 females) from the Congonhas Stream, Paranapanema River basin, Paraná state, Brazil, were analyzed. Metaphase chromosomes were prepared according to Bertollo et al. (1978) and analyzed by conventional Giemsa staining. Chromosomal morphology was determined based on the length ratio of the arms in accordance to Levan et al. (1964). The metacentric (m), submetacentric (sm), and subtelocentric (st) chromosomes were considered to present two arms, and the acrocentric (a) chromosomes only one arm.

\section{Results and Discussion}

All the examined specimens showed a diploid number of 56 chromosomes (Figure 1), a relevant characteristic of Pimelodus maculatus that has been found in all populations of this species already studied (Borin and Martins-Santos, 2002; Souza et al., 2003; Treco, 2007). This characteristic is also seen in most of the species of the genus Pimelodus (Souza et al., 2004; Garcia and Moreira-Filho, 2005), which indicates a conservation in the diploid number for this fish group. Exceptions were found by Della-Rosa et al. (1980) in Pimelodus blochii from the Solimões River, Amazonas State, with $2 \mathrm{n}=58$ chromosomes, and by Garcia and Moreira-Filho (2005) in Pimelodus fur from the São Francisco River, Minas Gerais State, showing $2 n=54$ chromosomes.

Oliveira and Gosztonyi (2000) suggested that $2 n=56$ chromosomes is the ancestral diploid number for Siluriformes. If so, this diploid number could be considered a plesiomorphic condition in the genus Pimelodus, and, consequently, its variations could be apomorphic characteristics, as suggested by Garcia and Moreira-Filho (2005).

The karyotype formula of $P$. maculatus from the Congonhas Stream was composed by 20 metacentric, 20 submetacentric, 10 subtelocentric, and 6 acrocentric chromosomes with a fundamental number $(\mathrm{FN})$ of 106 for both sexes (Figure 1). This karyotype formula corresponds to that found in some other populations of

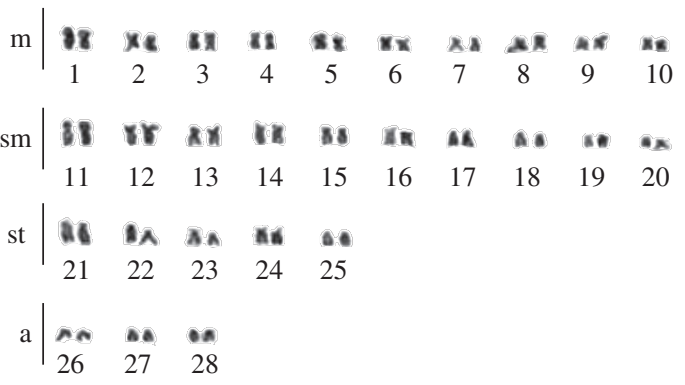

Figure 1. Standard karyotype of Pimelodus maculatus from the Congonhas Stream, Paranapanema River basin, with $20 m+20 s m+10 s t+6 a$.
P. maculatus previously studied (Vissotto et al., 1999; Swarça et al., 2001; Borin and Martins-Santos, 2002), although variations have been reported for other populations of this species, as well as for others species of the genus Pimelodus (Treco, 2007). Specimens of P. maculatus from the São Francisco River, for example, showed a karyotype with $32 \mathrm{~m}, 12 \mathrm{sm}, 12$ st chromosomes, and FN = 112 (Garcia and Moreira-Filho, 2005), and $P$. maculatus from the Paraguai River (Mato Grosso do Sul State) showed 22 m, 16 sm, 10 st, 8a chromosomes, and FN = 104 (Souza et al., 2003). These variations among some populations of $P$. maculatus indicate the occurrence of chromosomal rearrangements, such as inversions and/or translocations during the evolutionary process of this fish group, resulting on distinct chromosomal formula but constant diploid number $(2 n=56)$.

Four individuals of $P$. maculatus from the Congonhas Stream, 2 males and 2 females, presented a variant karyotype (cytotype). These specimens showed the same diploid number $(2 n=56)$ and the same karyotype formula $(20 m+20 s m+10 s t+6 a)$ found in the standard karyotype, but the submetacentric chromosomes presented an irregular pairing with two heteromorphic chromosomes, one of them corresponds to the second largest chromosome of this group and the other is a chromosome of small size (Figure 2). $\mathrm{C}$-chromosome banding could not be carried out in order to identify if this heteromorphism is related to heterochromatic segments and to better clarify its probable origin. However, some cases of polymorphisms due to loss of segments and that are well tolerated by the individuals have already been reported in Neotropical fish

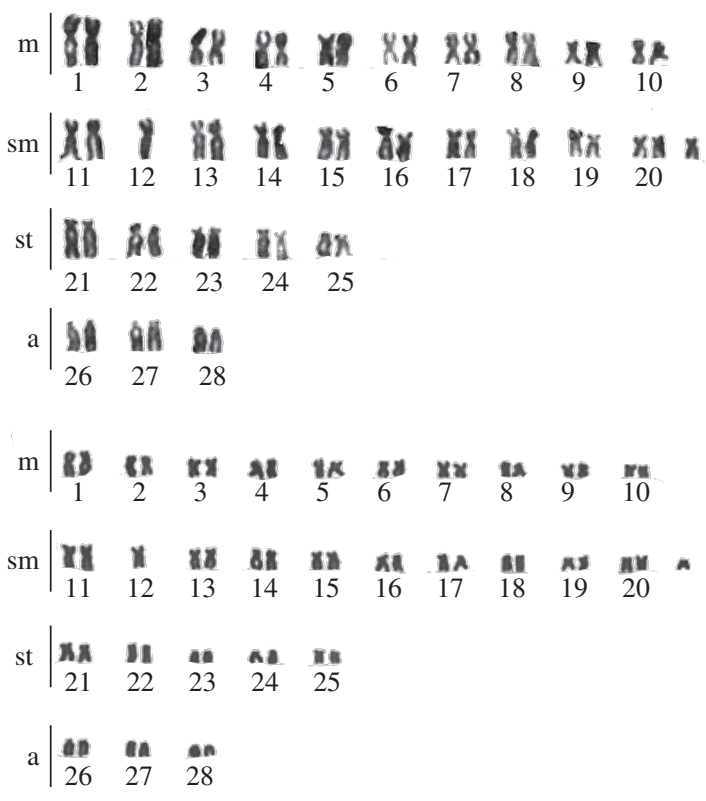

Figure 2. Variant karyotypes (cytotypes) showing heteromorphism in the group of submetacentric chromosomes. 
species (Oliveira et al., 1993; Mizoguchi and MartinsSantos, 1998).

Despite the lack of chromosomal marks that impairs a more conclusive analysis, the results presented here suggest the occurrence of a structural polymorphism in the analyzed population of $P$. maculatus from the Congonhas Stream, which is not related to sex since it was found in both males and females. Similar results were also found in another population of Pimelodus maculatus and in Pimelodus sp. (Dias and Foresti, 1993), from the São Francisco River basin (Minas Gerais State, Brazil), related to a size heteromorphism on a subtelo/ acrocentric chromosome pair, suggesting to be derived from a pericentric inversion followed by a small deletion. These data indicate that, despite the constancy in the diploid number, the genus Pimelodus has undergone a structural karyotype diversification, in particular the species $P$. maculatus. The polymorphic conditions may be associated with the distinct environments where these species are found.

Acknowledgments - The authors are grateful to PIBIC/CNPq and Fundação Araucária for their financial support. Dr. Albert Leyva helped in the preparation of the manuscript.

\section{References}

BERTOLLO, LAC., TAKAHASHI, CS. and MOREIRAFILHO, O., 1978. Cytotaxonomic considerations on Hoplias lacerdae (Pisces, Erythrinidae). Rev. Bras. Genet., vol. 1, no. 2, p. 103-120.

BORIN, LA. and MARTINS-SANTOS, IC., 2002. Cytogenetics aspects in species of the genus Pimelodus (Pisces, Siluriformes, Pimelodidae) of the river Paraná basin. Cytologia, vol. 67, no. 2, p. 199-204.

-, 2004. Study on karyotype and occurrence of B chromosome in two species of the genus Pimelodus (Siluriformes, Pimelodidae) from the River Iguaçu. Hereditas, vol. 140, no. 3, p. 201-209.

DELLA-ROSA VA., BERTOLLO LAC., FERRARI I., MOREIRA-FILHO, O. and FORESTI F., 1980. Estudos citogenéticos de peixes da Amazônia. II Ordem Siluriformes. Ciênc. e Cult., vol. 32, p. 735.

DIAS AL. and FORESTI F., 1993. Cytogenetic studies on fishes of the family Pimelodidae (Siluroidei). Rev. Bras. Genet., vol. 6 , no. 3 , p. 585-600.
GALETTI, PM., 1998. Chromosome diversity in neotropical fishes: NOR studies. Ital. J. Zool., vol. 65, p. 53-56.

GARCIA, C. and MOREIRA-FILHO, O., 2005. Cytogenetical analyses in three fish species of the genus Pimelodus (Siluriformes, Pimelodidae) from São Francisco river: considerations about the karyotypical evolution in the genus. Neotrop. Ichtyol., vol. 3, no. 2, p. 285-290.

LEVAN, A., FREDGA, K. and SANDBERG, AA., 1964. Nomenclature for centromeric position on chromosomes. Hereditas, vol. 52, p. 201-220.

MIZOGUCHI, SMHN. and MARTINS-SANTOS, IC., 1998. Cytogenetic and morphometric differences in populations of Astyanax scabripinnis (Pisces, Characidae) from Maringá region, PR, Brazil. Genet. Mol. Biol., vol. 21, no. 1, p. 55-61.

OLIVEIRA, C., ALMEIDA-TOLEDO, LF., MORY, L. and TOLEDO-FILHO, S., 1993. Cytogenetic and DNA content in six genera of the family Callichthyidae (Pisces, Siluriformes). Caryologia, vol. 46, no. 2-3, p. 175-188.

OLIVEIRA, C. and GOSZTONYI, AE., 2000. A cytogenetic study of Diplomystes mesembrinus (Teleostei, Siluriformes, Diplomystidae) with a discussion of chromosome evolution in siluriforms. Caryologia, vol. 53, no. 1, p. 31-37.

SOUZA, L., GIULIANO-CAETANO, L. and DIAS, AL., 2003. Karyotipic study of three species of Pimelodus (Pisces, Pimelodidae) from the Paraná river basin. Cytologia, vol. 68, no. 4 , p. $345-350$.

-, 2004. Banding chromosome pattern of two species of Pimelodus (Siluriformes, Pimelodidae) from the Paraná river basin of Brazil. Folia Biol.-Krakow, vol. 52, p. 165-169.

SWARÇA, AC., GIULIANO-CAETANO, L. and DIAS, AL. 2001. Analyses of nucleolus organizer regions and heterochromatin of Pimelodus maculatus (Pisces, Pimelodidae). Genetica, vol. 110, p. 97-100.

TRECO, FR., 2007. Estudos citogenéticos em espécies de peixes da família Pimelodidae pertencentes a diferentes bacias hidrográficas. 75p. (Dissertação de Mestrado) - UEL, Londrina, PR.

VISSOTO, PC., FORESTI, F. and OLIVEIRA C., 1999. Karyotype description of five species of Pimelodidae (Teleostei,Siluriformes). Chromosome Sci., vol. 3, p. 1-7. 
